\title{
IMPLEMENTASI KEBIJAKAN FUNGSI PUSKESMAS SELAMA PANDEMI COVID 19 DI PUSKESMAS MARGAHAYU SELATAN KABUPATEN BANDUNG
}

\author{
Yulianti Hasanah ${ }^{1}$, Ratna Meisa Dai ${ }^{2}$, Deasy Silvya Sari ${ }^{3}$ \\ ${ }^{1}$ Magister Kebijakan Publik, Fakultas Ilmu Sosial dan Politik, Universitas Padjajaran \\ ${ }^{2}$ Departemen Administrasi Publik, Fakultas Ilmu Sosial dan Politik, Universitas Padjajaran \\ ${ }^{3}$ Departemen Hubungan Internasional, Fakultas Ilmu Sosial dan Politik, \\ Universitas Padjajaran \\ yulianti_hasanah@ymail.com,ratna.meisa.dai@unpad.ac.id,deasy.silvya@unpad.ac.id
}

\begin{abstract}
ABSTRAK
Pusat Kesehatan Masyarakat (Puskesmas) menggambarkan suatu pelayanan publik yang bergerak dalam bidang pelayanan kesehatan memiliki peranan yang penting dalam Sistem Kesehatan Nasional. Dalam mendukung Pembangunan di bidang kesehatan, Puskesmas mempunyai peran melaksanakan kebijakan di bidang Kesehatan. Diamanahkan bahwa untuk melaksanakan tugasnya dalam pembangunan kesehatan, Puskesmas mempunyai peran melaksanakan Upaya Kesehatan Masyarakat (UKM) dan Upaya Kesehatan Perorangan (UKP). Adapun kebijakan yang mengatur tentang Puskesmas adalah Peraturan Menteri Kesehatan no 43 th 2019 dimana pada masa pandemic covid 19 tidak bisa dilaksanakan optimal karena sifat virus covid 19 yang menyebar cepat tidak memungkinkan untuk melaksanakan dua fungsi puskesmas secara normal. Beberapa kebijakan internal dikeluarkan untuk mendukung tetap dilaksanakannya fungsi puskesmas seperti yang diamanahkan, tetapi memiliki tujuan melindungi tenaga kesehatan dan masyarakat yang memanfaatkan pelayanan di puskesmas dari kemungkinan terpaparnya virus covid 19 di fasilitas kesehatan/puskesmas. Artikel ini bertujuan untuk menjelaskan implementasi kebijakan fungsi Puskesmas selama pandemi Covid 19 dengan lokus Puskesmas Margahayu Selatan, Kabupaten Bandung. Metode penelitian yang dilakukan yaitu mix methode dengan perhitungan sampel berdasarkan metode Slovin dilakukan penyebarluasan kuesioner kepada masyarakat sebagai penerima manfaat sedangkan kualitatif dengan menggunakan wawancara mendalam kepada stakeholders. Penulis menemukan bahwa Puskesmas Margahayu Selatan telah menjalankan fungsi Puskesmas sebagaimana amanah Peraturan Menteri Kesehatan no. 43 tahun 2019, yakni fungsi sebagai Upaya Kesehatan Perorangan dan Upaya Kesehatan Masyarakat, tetapi diperlukan strategi khusus untuk tetap menjaga kualitas pelayanan di Puskesmas untuk diperoleh capaian sesuai dengan Standar Pelayanan Minimal yang tertuang dalam Penilaian Kinerja.
\end{abstract}

Kata kunci: Fungsi Puskesmas, Implementasi Kebijakan, Covid 19 


\begin{abstract}
The Community Health Center (Puskesmas) is one of the public services engaged in the health services that has an important role in the national health system. In supporting development in the health sector, Puskesmas has the task of implementing policies in the field of Health. It is mandated that ti carru out ts duties in health development, Puskesmas has the function of carrying out efforts. Public health (UKM) and Health efforts individual (UKP). The policy that regulates puskesmas is Minister of helth Regulation No 43 of 2019 which during the Covid 19 pandemic cannot be carried

out optimally bcause the fast sprading nature of the Covid 19 virus makes it impossible to carry out the two function of the Puskesmas normally. Several internal policies wer issued tio support the continued implementation of the function of the puskesmas as mandated, but with the aim of protecting halth workers and public who utilize services at th puskesmas from mthe possibility of exposure to th covid 19 virus in health facilities/puskesmas, This articles aims to explain the implementation of the Puskesmas function policy during the covid 19 pandemi with the margahayu selatan Puskesmas locus Bandung regency. The research method used is a mix method with a sample calculation based on the slovin method by distributing questionnaires to the community as beneficiaries the community as beneficiaries, while qualitatively using in depth interviews stakeholders. The author found that Puskesmas margahayu selatan has carries out the function of the Puskesmas asa mandated by the minister of Health Regulation no 43 of 2019, which is a function of individual health efforts and public health efforts, a special strategy is needed to maintain the quality of services at the Puskesmas to obtain achievements in accordance with the minimum services standars contained in the performance assessment.
\end{abstract}

Key words: Puskesmas function, Policy Impementation, Covid 19 


\section{PENDAHULUAN}

Pada Rakernas tahun 2020 membahas mengenai arah kebijakan pembangunan kesehatan yaitu meningkatkan akses dan kualitas pelayanan kesehatan dengan peningkatan preventif promotif untuk menghasilkan sumber daya manusia unggul menuju Indonesia maju 2045(Tema Rakernas Kementerian Kesehatan 2020).

Puskesmas mengemban tugas untuk melaksanakan pembangunan kesehatan di wilayah kerjanya. Adapun tujuan pelaksanaan pendirian Puskesmas ialah menjadikan masyarakat yang sehat dengan perilaku sehat didasari kesadaran, kemauan dan kemampuan masyarakat untuk hidup sehat dan mendapat kemudahan dalam mendapatkan pelayanan kesehatan yang berkualitas, berada dalam lingkungan yang sehat yang meliputi individu, keluarga, kelompok dan masyarakat di wilayah kerjanya. Peraturan yang mengatur tentang puskesmas adalah Peraturan Menteri Kesehatan Republik Indonesia no 43 tahun 2019 tentang Pusat Kesehatan Masyarakat, yang menyebutkan Puskesmas sebagai Sarana kesehatan yang melayani langsung masyarakat memiliki fungsi sebagai upaya kesehatan masyarakat (UKM) dan upaya kesehatan perseorangan (UKP) tingkat pertama yang mengedepankan upaya pencegahan (preventif) dan promotif untuk mencapai tujuan pembangunan di bidang kesehatan yaitu meraih derajat kesehatan masyarakat yang maksimal didaerah kerjanya.

Awal 2020, dunia menghadapi pandemi diakibatkan virus jenis baru yaitu Covid 19. Wabah ini telah berkembang dengan sangat cepat. Data kasus covid yang tercatat sampai tanggal 9/7/2020, Berdasarkan data dari WHO adalah 11.84.226 kasus diketahui positif dan terjadi 545.481 meninggal sedunia dengan Case Fatality Rate/CFR 4,6\%. Indonesia pertamakali mengumumkan kasus tanggal 2 Maret 2020. Kasus yang terjadi di Indonesia semakin tinggi serta meluas sampai kesemua kawasan Indonesia.
Dilaporkan dari Kementerian Kesehatan hingga tanggal 9/7/2020 tercatat 70.736 kasus tercatat positif Covid 19 beserta 3.417 meninggal dunia (CFR 4,8\%) (Pedoman Pencegahan dan Pengendalian Covid 19, Kepmenkes HK.01.07/MENKES/413/2020.

Kondisi pandemi yang semakin meluas dan melanda 33 provinsi di Indonesia dengan jumlah kasus dan kematian yang bertambah tinggi tentu memiliki akibat pada aspek lain di luar kesehatan seperti politik, budaya pariwisata, ekonomi, pertahanan keamanan dan kesejahteraan masyarakat di Indonesia. Pemerintah Indonesia telah mengeluarkan beberapa kebijakan yaitu Keputusan Presiden Nomor $11 \quad$ Tahun 2020 tentang Penetapan Kedaruratan Kesehatan Masyarakat Corona Virus Disease 2019 (COVID-19), Kepres No. 12/2020 mengenai Penetapan Bencana Non alam.Penyebaran Corona Virus Disease 2019 sebagai Bencana Nasional. Kemudian, menerapkan Pembatasan Sosial Berskala Besar diputuskan dengan PP No. 21/2020 mengenai Pembatasan Sosial Berskala Besar dalam Rangka Percepatan Penanganan Corona Virus Disease 2019 (COVID-19), dan secara teknis dituangkan pada Permenkes No. 9/2020 mengenai Pedoman Pembatasan Sosial Berskala Besar Dalam Rangka Percepatan Penanganan Corona Virus Disease 2019. Peraturan tersebut menjadi dasar pembatasan sosial di berbagai sektor termasuk di Kesehatan.

Melihat dari sifat virus yang sangat mudah menular, maka Pemerintah mengeluarkan kebijakan mengenai Social Distancing dan Physical Distancing sebagai upaya mencegah penularan covid.

Peraturan Menteri Kesehatan No.43/2019 tentang Puskesmas telah mengatur fungsi Puskesmas sebagai Pelayanan Kesehatan yang berhadapan langsung dengan masyarakat untuk menjalankan fungsi UKM (Upaya Kesehatan Masyarakat) yang mengedepankan pemberdayaan 
masyarakat sebagai konsep paradigma sehat yang menekankan preventif promotif, dan fungsi UKP (Upaya Kesehatan Perorangan). Kedua fungsi ini menjadi sayap Puskesmas dalam menjalankan peranannya dimasyarakat untuk meraih kepercayaan masyarakat dengan mengedepankan mutu pelayanan dalam konsep manajemen yang sehat.

Puskesmas Margahayu Selatan, merupakan salah satu puskesmas di wilayah perkotaan Kabupaten Bandung. Kondisi pandemi Covid 19 tentu memberi dampak dalam pelayanan di Puskesmas untuk menjalankan fungsinya sebagai Upaya Keshatan Perorangan (UKP) dan Upaya Kesehatan Masyarakat (UKM). Di dalam gedung untuk menjalani fungsinya sebagai UKP, berbagai kebijakan internal diberlakukan sehingga SOP (standar Operasional Prosedur) pelaksanaan pelayanan dalam gedung banyak yang dirubah termasuk alur pelayanan pasien. Sedangkan pelaksanaan fungsi Upaya Kesehatan Masyarakat sudah pasti berdampak besar karena tidak dimungkinkan adanya keramaian dan mengumpulkan masa maka kegiatan di Pos Pelayanan Terpadu (Posyandu), Pos Binaan Terpadu (Posbindu) penyuluhan luar gedung ke sekolah dan masyarakat termasuk bulan Imunisasi Sekolah (BIAS) ditiadakan sementara, Demikian pula dalam menjalankan fungsi manajemen dimana kegiatan perencanaan membutuhkan perubahan anggaran untuk penanganan covid yang membutuhkan logistik seperti kesediaan Alat Pelindung Diri (APD) yang memadai, penunjang pemeriksaan laboratorium, Sumber Daya Manusia (SDM) yang kompeten hingga sarana prasarana yang menujang diterapkannya protokol Kesehatan. Sampai dengan Bulan Mei th 2020 di Puskesmas Margahayu, didapat data positif kasus covid sebanyak dua orang Dengan adanya kasus terkorfirmasi positif di wilayah kerja Puskesmas menjadikan Kecamatan Margahayu di mana Puskesmas margahayu selatan berada termasuk zona merah. Berdasarkan uraian di atas, maka sebagai bagian dari pelayanan kesehatan di wilayah Kabupaten Bandung, Puskesmas margahayu selatan termasuk yang terkena dampak dari adanya pandemi covid 19 . Manajemen perlu membuat strategi agar Puskesmas tetap dapat melaksanakan fungsi yang diamanatkan oleh Permenkes 43 th 2019 dengan tujuan menjamin kualitas pelayanan di Puskesmas tetap terjaga dan melindungi dari kemungkinan terpaparnya penyakit iinfeksi termasuk covid bagi pasien dan karyawan di Puskesmas. Untuk pelayanan di dalam gedung yang berhadapan langsung dengan masyarakat sebagai fungsi Upaya Kesehatan Perorangan dibutuhkan strategistrategi khusus. Sedangkan untuk fungsi Upaya Kesehatan Masyarakat yang mengedepankan preventif promotif, penyebaran covid yang sangat cepat memaksa Puskesmas tidak melaksanakan berbagai kegiatan yang mengumpulkan masa, tentu saja memiliki akibat capaian kinerja yang tidak mencapai target sesuai Standar Pelayanan Minimal (Permenkes ni 4 tentang standar tekhnis pemenuhan mutu pelayanan dasar bidang kesehatan) yang menjadi keluaran dari Penilaian Kinerja Puskesmas.Oleh karena itu,artikel ini bertujuan untuk menjelaskan implementasi kebijakan Fungsi Puskesmas selama pandemi COVID 19 di Puskesmas Margahayu Selatan, Kabupaten Bandung.

\section{TINJAUAN PUSTAKA}

Implementasi Kebijakan Publik Pengertian implementasi menurut Grindle adalah Proses umum berupa tindakan administatif yang bisa diteliti dan dapat 
dilakukan apabila telah diputuskan apa yang menjadi goalnya, siapa yang menjadi sasarannya dan apa program kegiatan yang telah disusun tentu ditunjang oleh dana yang ada.

"Ada dua variabel besar yang akan mempengaruhi keberhasilan dari suatu implementasi menurut Grindle yaitu isi dari suatu kebijakan (content of policy) dan konteks kebijakan Implementasi (context implementation)"

Dalam konteks isi kebijakan menurut Grindle yaitu; 1)Sampai mana kepentingan suatu kelompok yang menjadi sasaran kebijakan termaktub dalam suatu kebijakan ; 2) Apa kegunaan dari kebijakan terhadap target grup/sasaran; 3) Apa output yang diharapkan sebuah kebijakan dapat menjadikan perubahan? ; 4) Dimana suatu program berada dari suatu kebijakan , apakah sudah benar/tepat? ; 5) Apakah implementornya sudah disebutkan oleh suatu kebijakan dengan rinci;6) Apakah ada dukungan sumber daya yang memadai untuk suatu program.Sedangkan, variabel konteks kebijakan mencakup: 1) Sejauh mana keterlibatan para aktor dalam implementasi kebijakan dalam hal kekuasaan, kepentingan, dan strategi.;2) karakteristik Institusi dan penguasa; 3) Bagaimana tingkat kepatuhan dan responsivitas kelompok sasaran

Dilihat dari item di atas maka perlu diketahui yaitu: Strategi, sumber dan posisi kekuasaan implementor akan menentukan tingkat keberhasilan dari implementasi suatu kebijakan. Bila suatu kekuatan memiliki kepentingan terhadap suatu program maka pasti akan membuat taktik bagaimana memenangkan kompetisi sehingga keluaran yang diharapkan optimal sesuai yang diharapkan.

\section{Fungsi Puskesmas sesuai dengan Permenkes 43 th 2019}

Puskesmas adalah salah satu pelayanan publik yang melaksanakan pelayanan di bidang kesehatan memiliki peranan penting dalam sistem Kesehatan nasional. Dalam Pasal 4 disebutkan bahwa Puskesmas memiliki tugas melaksanakan kebijakan di bidang Kesehatan sesuai tujuan pembangunan yaitu guna memperoleh derajat kesehatan yang maksimal di tempat kerjanya.Dalam melaksanakan tugasnya, Puskesmas memiliki fungsi melaksanakan Upaya Kesehatan Masyarakat (UKM) dan Upaya Kesehatan Perorangan (UKP). Dalam melaksanakan fungsi sebagai UKM maka puskesmas memiliki kewenangan untuk; (1) Melakukan analisa masalah kesehatan dan analisa kebutuhan masyarakat untuk pelayanan yang dibutuhkan sebagai dasar melaksanakan perencanaan, (2) Melakukan pendekatan dan menginformasikan suatu kebijakan di bidang Kesehatan, (3) Melaksanakan fungsi promosi yaitu KIE ( komunikasi, informasi, edukasi) serta melakukan pemberdayaan masyarakat di bidang Kesehatan, (4) Bekerjasama dengan lintas sector untuk menghidupkan publik mendata serta menyudahi persoalan Kesehatan, (5) pembinaan Tekhnis terhadap sarana kesehatan swasta (jaringan) pelayanan dan upaya yang dilakukan di bidang Kesehatan dengan memberdayakan masyarakat, Melakukan upaya untuk Meningkatkan kemampuan. Petugas kesehatan sebagai sumber daya di puskesmas, (7) Melakukan pemantauan untuk melaksanakan pembangunan yang memiliki wawasan Kesehatan, (8) Dilakukan tertib administrasi berupa membuat catatan, laporan dan dilakukan evaluasi terhadap jangkauan pelayanan kesehatan, kualitas, serta cakupan pelayanan di bidang Kesehatan dan (9) memberikan rekomendasi yang berhubungan dengan masalah Kesehatan masyarakat, termasuk 
dukungan terhadap System Kewaspadaandini serta tanggapan penanggulangan penyakit. Sedangkan wewenang Puskesmas dalam penyelenggaraan UKP tingkat pertama di wilayah kerjanya meliputi:1) Melaksanakan pelayanan di bidang kesehatan kepada masyarakat yang bersifat dasar secara keseluruhan, berkelanjutan dan berkualitas (2). Melaksanakan pelayanan di bidang kesehatan yang mengedepakan promotif dan preventif, (3) pelayanan di bidang Kesehatan yang dilakukan tujuannya pada pribadi, keluarga, kelompok dan. masyarakat, (4) Dalam melaksanakan pelayanan di bidang kesehatan mengedepankan keamanan dan keselamatan pasien, karyawan dan masyarakat yang datang ke puskesmas, (5). Dalam melaksanakan pelayanan di bidang Kesehatan melakukan prinsip koordinasi dan kerjasama didalam dan di luar profesi (6) melaksanakan kegiatan administrasi berupa pencatatan dokumentasi riwayat pengobatan pasien, (7)Tertib administrasi dalam membuat catatan, laporan dan evaluasi untuk menjaga kualitas dan jangkauan dari suatu pelayanan kesehatan (8) Untuk mendapatkan petugas kesehatan yang kompeten maka dilakukan upaya peningkatan kompetensi petugas kesehatan, (9).Melakukan koordinasi dan pemantauan terhadap pelayanan bidang Kesehatan di tempat kerjanya (10) Puskesmas memilah pasien berdasarkan diagnose dan indikasi gejala untuk menentukan pelayanan dilakukan di dalam atau dilakukan rujukan.

\section{Pandemi COVID 19}

Pandemi Covid 19 disebabkan oleh Coronavirus Disease 2019 (COVID-19).
Penyakit ini merupakan penyakit yang menular dengan cepat. Pertamakali muncul di Wuhan, China akhir Desember 2019 (Li et al, 2020). Memiliki masa inkubasi $1 \mathrm{~s}$ ampai dengan 14 hari. Ada Risiko penularan yang tinggi karena kepekatan sekret yang tinggi. Pada orang yang terkena dari secret maka bias menyebarkan sampai 48 jam sebelum terlihat tanda-tanda (presimptomatik) sampai 14 hari sesudah terlihat tanda-tanda. Sebuah studi Du Z et. al, (2020) membaritahukan bahwa 12,6\% dari hasil penelitiannya ternyata menunjukkan penularan presimptomatik. Ini adalah periode yang penting untuk diketahui karena virus sangat mungkin menempel pada benda melalui droplet orang yang terinfeksi.Pada beberapa kasus, ada konfirmasi positif tanpa gejala, (asimptomatik), walaupun demikian tetap memiliki resiko penularan.

\section{METODE PENELITIAN}

Penelitian dilaksanakan untuk mengetahui implementasi dari Permenkes no. 43 tahun 2019 dikaitkan dengan fungsi puskesmas sebagai Upaya Kesehatan Perorangan (UKP) dan Upaya Kesehatan Masyarakat (UKM) di saat pandemic covid 19. Pada penelitian ini, penulis mengggunakan metode mix methode sehingga penelitian dilakukan melalui kombinasi kualitatif dan kuantitatif. Jenis Data, dan sumber data yang digunakan dalam penelitian ini diperoleh melalui wawancara, observasi lapangan dan pembagian kuesioner melalui form goggle drive.

Tabel 1

Jenis data yang dikumpulkan, Teknik Pengumpulan Data, Instrumen, dan Sumber Data 
Implementasi Kebijakan Fungsi Puskesmas Selama Pandemi Covid 19 Di Puskesmas Margahayu Selatan Kabupaten Bandung (Yulianti Hasanah, Ratna Meisa Dai, Deasy Silvya Sari)

\begin{tabular}{|c|c|c|c|c|}
\hline $\mathrm{NO}$ & JENIS DATA & $\begin{array}{c}\text { TEKHNIK } \\
\text { PENGUMPULAN } \\
\text { DATA }\end{array}$ & INSTRUMEN & SUMBER DATA \\
\hline 1 & $\begin{array}{lr}\text { Pendapat masyarakat } \\
\text { mengenai implementasi } \\
\text { kebijakan puskesmas } \\
\text { dalam melaksanakan } \\
\text { fungsinya di saat } \\
\text { pandemi covid } 19\end{array}$ & $\begin{array}{l}\text { Kuesioner } \\
\text { (kuantitatif) }\end{array}$ & $\begin{array}{l}\text { Lembar } \\
\text { kuesioner (link } \\
\text { gogle drive) }\end{array}$ & Masyarakat \\
\hline 2. & \begin{tabular}{lr}
\multicolumn{3}{l}{ Kebijakan dan } & strategi \\
yang digunakan & oleh \\
stake holder di & Dinas \\
Kesehatan & untuk \\
puskesmas & tetap \\
melaksanakan & \\
fungsinya di & saat \\
pandemi covid 19 & \\
\end{tabular} & $\begin{array}{l}\text { Wawancara } \\
\text { mendalam }\end{array}$ & $\begin{array}{l}\text { Panduan } \\
\text { wawancara } \\
\text { (online dan } \\
\text { tatap muka) }\end{array}$ & $\begin{array}{l}\text { Stake holder di } \\
\text { Dinas Kesehatan }\end{array}$ \\
\hline 3. & $\begin{array}{l}\text { Kebijakan dan strategi } \\
\text { yang digunakan oleh } \\
\text { manajemen Puskesmas } \\
\text { untuk melaksanakan } \\
\text { fungsinya di saat } \\
\text { pandemi covid } 19\end{array}$ & $\begin{array}{l}\text { Wawancara } \\
\text { mendalam }\end{array}$ & $\begin{array}{l}\text { Panduan } \\
\text { wawancara } \\
\text { (online dan } \\
\text { tatap muka) }\end{array}$ & $\begin{array}{l}\text { Manajemen } \\
\text { Puskesmas Marsel } \\
\text { (kepala } \\
\text { puskesmas, ketua } \\
\text { pokja UKM, ketua } \\
\text { pokja UKP) }\end{array}$ \\
\hline 4. & $\begin{array}{lr}\text { Pelaksanaan } & \text { fungsi } \\
\text { UKP UKM } & \text { di } \\
\text { puskesmas }\end{array}$ & $\begin{array}{l}\text { Observasi } \\
\text { (kualitatif) }\end{array}$ & $\begin{array}{l}\text { Lembar untuk } \\
\text { catatan } \\
\text { lapangan }\end{array}$ & $\begin{array}{l}\text { Proses pelayanan } \\
\text { dalam dan luar } \\
\text { Gedung }\end{array}$ \\
\hline
\end{tabular}

Tabel 2

Informan dalam pelaksanaan studi kasus Implementasi kebijakan Puskesmas dalam menjalankan fungsinya di saat adanya pandemic covid 19 di Puskesmas Margahayu Selatan Kabupaten Bandung

\begin{tabular}{|l|l|l|c|}
\hline No & \multicolumn{1}{|c|}{ Informan } & \multicolumn{1}{|c|}{$\begin{array}{c}\text { Informasi yang } \\
\text { diharapkan }\end{array}$} & Jumlah orang \\
\hline 1. & Kepala Puskesmas & $\begin{array}{l}\text { Kebijakan dan } \\
\text { Pelaksanaan Fungsi } \\
\text { Puskesmas sebagai UKP } \\
\text { dan UKM di saat adanya } \\
\text { pandemi covid 19 }\end{array}$ & 1 orang \\
\hline 2. & PJ UKM & $\begin{array}{l}\text { Strategi pelaksanaan } \\
\text { fungsi UKM di saat } \\
\text { adanya pandemi covid 19 }\end{array}$ & 1 orang \\
\hline 3. & PJ UKP & $\begin{array}{l}\text { Strategi pelaksanaan } \\
\text { fungsi UKP di saat adanya } \\
\text { pandemi covid 19 }\end{array}$ & 1 orang \\
\hline
\end{tabular}




\begin{tabular}{|c|c|c|c|}
\hline 4. & $\begin{array}{l}\text { Kasubag penyusunan } \\
\text { program informasi dan } \\
\text { humas Dinas Kesehatan }\end{array}$ & $\begin{array}{lr}\begin{array}{l}\text { Perubahan } \\
\text { terkait }\end{array} & \text { kebutuhanan } \\
\text { puskesmas } & \text { saat adanya } \\
\text { pandemi covid } 19\end{array}$ & 1 orang \\
\hline 5. & $\begin{array}{l}\text { Kasie Promkes Dinas } \\
\text { Kesehatan }\end{array}$ & $\begin{array}{lr}\text { Kebijakan dan } & \text { strategi } \\
\text { dan Program } & \text { Promosi } \\
\text { Kesehatan } & \text { sebagai } \\
\text { penunjang fungsi UKM } \\
\text { saat adanya pandemi } \\
\text { covid 19 }\end{array}$ & 1 orang \\
\hline 6. & $\begin{array}{l}\text { Kasie Mutu Dinas } \\
\text { Kesehatan }\end{array}$ & $\begin{array}{lr}\text { Kebijakan dan strategi } \\
\text { Dinkes bagi } & \text { Puskesmas } \\
\text { dalam menjalankan fungsi } \\
\text { Puskesmas saat } & \text { pandemi } \\
\text { covid } 19 & \text { untuk } \\
\text { meningkatkan } & \text { mutu } \\
\text { pelayanan } & \end{array}$ & 1 orang \\
\hline 7. & Kasie Yankes Primer & $\begin{array}{lr}\text { Kebijakan dan strategi } \\
\text { Dinkes bagi } & \text { Puskesmas } \\
\text { dalam menjalankan fungsi } \\
\text { Puskesmas saat } & \text { pandemi } \\
\text { covid } 19 & \text { untuk } \\
\text { meningkatkan } & \text { mutu } \\
\text { pelayanan } & \end{array}$ & 1 orang \\
\hline
\end{tabular}

\begin{tabular}{|l|l|l|l|}
\hline 8. & masyarakat & $\begin{array}{l}\text { Pelayanan Puskesmas } \\
\text { sesuai fungsi di mata } \\
\text { masyarakat saat adanya } \\
\text { pandemi covid 19 }\end{array}$ & metode slovin \\
\hline
\end{tabular}

\section{DISKUSI DAN PEMBAHASAN}

Hasil penelitian sesuai dengan teknik pengambilan data yang dilakukan yaitu mix method maka diperoleh hasil kuantitatif dan hasil kualitatif. Hasil penelitian kuantitatif pada penelitian ini menginformasikan pendapat masyarakat sebagai penerima manfaat pelayanan puskesmas terhadap kebijakan puskesmas di masa pandemi untuk tetap melaksanakan fungsinya. Kuesioner

disebarkan kepada masyarakat sebagai penerima manfaat melalui link google drive dengan media online. Hal ini dilakukan karena saat penelitian dilakukan dalam kondisi pandemi covid 19. Kuesioner dibagi menjadi 2 yaitu konten isi dan konten implementasi. Sesuai dengan teori implementasi grindle yang digunakan dalam penelitian ini.

Berikut adalah prosentase responden dalam menjawab pertanyaan mengenai implementasi kebijakan Puskesmas dalam menjalankan fungsinya di masa pandemi covid 19 dengan hasil tertera pada tabel sebagai berikut: 
Tabel 3

Prosentase responden dalam menjawab pertanyaan mengenai implementasi kebijakanfungsi puskesmas selama pandemi covid 19 di Puskesmas Margahayu Selatan

\begin{tabular}{|l|c|c|}
\hline \multicolumn{1}{|c|}{ URAIAN } & PROSENTASE \\
\cline { 2 - 3 } & YA & TIDAK \\
\hline KONTEN : ISI & & \\
\hline $\begin{array}{l}\text { Didalam kebijakan yang dilakukan puskesmas untuk tetap } \\
\text { menjalankan fungsinya di masa pandemic covid 19 memuat } \\
\text { kepentingan masyarakat }\end{array}$ & 87 & 13 \\
\hline $\begin{array}{l}\text { kebijakan yang telah dikeluarkan oleh puskesmas di masa } \\
\text { pandemic covid 19 ini berpengaruh terhadap pelayanan Kesehatan } \\
\text { di puskesmas }\end{array}$ & 59,3 & 40.7 \\
\hline $\begin{array}{l}\text { Kebijakanperubahan alur pelayanan dan pembatasan jumlah } \\
\text { pelayanan dalam dan luar Gedung dalam melaksanakan fungsi } \\
\text { puskesmas ini sudah tepat }\end{array}$ & 88,9 & 11.1 \\
\hline Masyarakat merasakan manfaat dari perubahan kebijakan & 87 & 13 \\
\hline $\begin{array}{l}\text { Masyarakat tidak mengalami kesulitan untuk mendapatkan } \\
\text { pelayanan di puskesmas }\end{array}$ & 74,1 & 25.9 \\
\hline $\begin{array}{l}\text { kebijakan puskesmas di saat pandemi ini dapat menekan } \\
\text { penambahan kasus covid 19 di wilayah Kerja puskesmas. }\end{array}$ & 75.9 & 24.1 \\
\hline $\begin{array}{l}\text { Kebijakan puskesmas telah merubah alur pelayanan di luar } \\
\text { gedung (fungsi ukm) }\end{array}$ & 87 & 13 \\
\hline $\begin{array}{l}\text { puskesmas telah merubah perilaku untuk menggunakan protocol } \\
\text { Kesehatan (menggunakan masker, jaga jarak dan cuci tangan }\end{array}$ & 98.1 & 1.9 \\
\hline $\begin{array}{l}\text { Kebijakan puskesmas telah sesuai dengan fungsinya (UKP ) dan } \\
\text { UKM }\end{array}$ & 96,3 & 3,7 \\
\hline $\begin{array}{l}\text { kebijakan puskesmas dalam melaksanakan pelayanan di saat } \\
\text { pandemic covid 19 mudah difahami }\end{array}$ & 94.3 & 5.7 \\
\hline $\begin{array}{l}\text { pelayanan yang diberikan oleh petugas puskesmas untuk } \\
\text { melaksanakan pelayanan fungsi UKP dan UKM sesuai dengan } \\
\text { kebijakan puskesmas }\end{array}$ & 98.1 & 1.9 \\
\hline $\begin{array}{l}\text { puskesmas telah menyebutkan rincian kegiatan yang dilakukan } \\
\text { mengenai pelayanan di saat pandemic covid 19 }\end{array}$ & 81.5 & 18.5 \\
\hline $\begin{array}{l}\text { MAsyarakat memahami tujuan perubahan kebijakan pelayanan } \\
\text { dalam dan luar Gedung di saat pandemic covid 19 }\end{array}$ & 90,7 & 9,3 \\
\hline $\begin{array}{l}\text { pelayanan puskesmas dalam melaksanakan fungsi di masa } \\
\text { pandemic covid 19 sudah didukung oleh sarana prasarana } \\
\text { pencegahan covid 19 }\end{array}$ & 88,9 & 11.1 \\
\hline $\begin{array}{l}\text { Pelayanan puskesmas di masa pandemic dalam melaksanakan } \\
\text { fungsi UKP dan UKM telah didukung oleh pelaksanan yang } \\
\text { kompeten }\end{array}$ & 92,6 & 7.4 \\
\hline KONTEKS : IMPLEMENTASI & \\
\hline
\end{tabular}




\begin{tabular}{|l|c|c|}
\hline $\begin{array}{l}\text { kebijakan puskesmas di masa pandemic membutuhkan } \\
\text { pemimpin yang memiliki kewenangan penuh }\end{array}$ & 90,4 & 9.6 \\
\hline $\begin{array}{l}\text { kebijakan puskesmas sejalan dengan kebijakan pemerintah di saat } \\
\text { pandemic covid 19 }\end{array}$ & 98.1 & 1.9 \\
\hline $\begin{array}{l}\text { puskesmas menerapkan sanksi jika masyarakat tidak mematuhi } \\
\text { kebijakan puskesmas dalam melaksanakan pelayanan di saat } \\
\text { pandemic covid 19 }\end{array}$ & 78,8 & 21.2 \\
\hline kebijakan puskesmas didukung oleh lintas sector di wilayah kerja & 94,2 & 5.8 \\
\hline $\begin{array}{l}\text { kebijakan puskesmas di saat pandemic menunjukkan karakteristik } \\
\text { puskesmas }\end{array}$ & 90,4 & 9.6 \\
\hline $\begin{array}{l}\text { kebijakan puskesmas di saat pandemic menunjukkan kualitas } \\
\text { puskesmas }\end{array}$ & 94,2 & 5.8 \\
\hline $\begin{array}{l}\text { MAsyarakat mematuhi kebijakan puskesmas dalam di saat } \\
\text { melaksanakan kegiatan pelayanan dalam Gedung(UKP) } \\
\text { pandemic covid 19 }\end{array}$ & 98,1 \\
\hline $\begin{array}{l}\text { Masyarakat mematuhi kebijakan puskesmas dalam melaksanakan } \\
\text { kegiatan pelayanan luar Gedung (UKM) }\end{array}$ & $94,2 \%$ & 5.8 \\
\hline $\begin{array}{l}\text { Masyarakat mengikuti perkembangan penanganan covid di } \\
\text { puskesmas. }\end{array}$ & 86,5 & 13.5 \\
\hline $\begin{array}{l}\text { Masyarakat mengetahui perkembangan penanganan covid di } \\
\text { puskesmas }\end{array}$ & 82,7 & 17,3 \\
\hline
\end{tabular}

Berdasarkan data di atas, maka diketahui bahwa dalam melaksanakan fungsi UKM dan UKM di puskesmas margahayu selatan, dikeluarkan beberapa kebijakan internal seperti perubahan alur masuk pasien saat berobat ke puskesmas, penggunaan Alat Pelindung Diri bagi tenaga kesehatan yang melakukan pelayanan langsung kepada masyarakat, penempatan sarana dan prasarana seperti tempat cuci tangan dan hand sanitizer di titik masuk pasien dan pemeriksaan screening/penafisan pasien untuk memilah pasien berdasarkan gejalanya maka berdasarkan kuesioner yang dibagkan kepada masyarakat sebagai kelompok penerima manfaat diperoleh hasil masyarakat faham bahwa perubahan pelayanan yang dilakukan adalah untuk kepentingan masyarakat (87\%), 88,9\% masyarakat menganggap kebijakan yang dikeluarkan sudah tepat, masyarakat tidak merasa kesulitan untuk tetap mendapatan pelayanan dalam gedung (74,1\%), kebijakan yang dikeluarkan telah merubah perilaku masyarakat dalam melakukan pengobatan di puskesmas (98,1\%) yaitu melaksanakan protocol kesehatan dan penggunaan sarana cuci tangan dan alat pelindung diri, puskemas telah menginformasikan kepada masyarakat tentang kebijakan yang dikeluarkan dalam masa pandemic (81,5\%). Adapun informasi disampaikan kepada masyarakat melalui RT /RW, dan pemanfaatan media social seperti WA group dan Instagram. Masyarakat pada dasarnya memahi tujuan dari perubahan kebijakan pelayanan baik di dalam maupun di luar gedung dalam menghadapi pandemic covid 19 (90,7\%), pelayanan puskesmas didukung oleh tenaga yang kmpeten $(92,6 \%)$ dan sarana prasarana yang memadai (88,9\%). Pertanyaan didasarkan pada tori grindle 
untuk konteks isi. Sedangkan dari konteks implementasi masyarakat berpendapat dalam masa pandemic kepala puskesmas perlu memiliki kewenangan penuh

(90,4\%), puskesmas berhak menerapkan sanksi bagi pasien yang melanggar (78,8\%), kebijakan yang dikeluarkan dianggap menunjukkan karakterisitik puskesmas $(90,4 \%)$ dan peraturan yang dikeluarkan oleh fasilitas kesehatan di masa pandemic menunjukkan kualitas puskesmas (94,2\%), kebanyakan masyarakat mematuhi peaturan yang dikeluarkan oleh puskesmas (98,1\%). Dan pelaksanaan fungsi UKM di puskesmas nampak dari diktahuinya masyarakat faham mengenai perkembangan penanganan covid 19 di puskesmas, hal ini menunjukkan bahwa puskesmas tetap melaksanakan fungsi UKM menyebarluaskan informasi kepada masyarakat mengenai penyakit covid dan penanganannya untuk preventif dan promotifnya. (82,7\%). Penyebarluasan informasi disampaikan melalui media social, media elektronik dan media cetak, serta penyuluhan langsung ke masyarakat melalui mobil keliling. Sedangkan untuk data kualitatif, pengambilan data dilakukan menggunakan wawancara dan observasi keadaan lapangan. Observasi dilaksanakan di puskesmas untuk melihat secara fakta bagaimana pelaksanaan puskesmas dalam menjalankan fungsinya sebagai Upaya Kesehatan Perorangan (UKP) dan Upaya Kesehatan Masyarakat (UKM) di masa pandemi Covid 19. Adapun hasil dari Observasi di lapangan adalah sebagai berikut:

Tabel 3

Hasil Observasi terhadap Implentasi Kebijakan Fungsi Puskesmas di Puskesmas Margahayu Selatan Kabupaten Bandung)

\begin{tabular}{|l|l|l|}
\hline No & Aspek yang diobservasi & Hasil Observasi \\
\hline 1. & Fungsi UKP & Terdapat perubahan pada fungsi puskesmas sebagai Upaya \\
& & Kesehatan Perorangan( UKP ) \\
& & 1.Perubahan Alur pelayanan : \\
& a. pada pintu masuk dilakukan screening pada pasien \\
& & yang dilakukan oleh petugas. Petugas screening \\
& & mngunakan Alat Pelindung Diri grade 2 mengecek \\
& & pasien menggunakan masker, cek suhu dengan \\
& & menggunakan thermal gun.Pasien diarahkan untuk \\
& & mencuci tangan terlebih dahulu sebelum \\
& & mendapatkan pelayanan.kemudian petugas \\
& & screening melakukan wawancara pada pasien \\
& &
\end{tabular}




\begin{tabular}{|c|c|c|}
\hline & & $\begin{array}{l}\text { b. Untuk pasien dengan gejala panas, batuk, pilek dan } \\
\text { sesak dipisahkan alurnya masuk ke ruangan UGD } \\
\text { yang dialihfungsikan saat pandemi covid } 19 \\
\text { ditangani oleh dokter dan perawat yang dilengkapi } \\
\text { dengan APD level } 2 \text { dan pembatas antara petugas } \\
\text { kesehatan dan pasien } \\
\text { c. Sedangkan untuk pasien tanpa gejala di atas masuk } \\
\text { dan menunggu di ruang tunggu untuk menunggu } \\
\text { dipanggil pada poli yang dituju } \\
\text { 2. Tidak ada pembatasan jumlah kunjungan, karena } \\
\text { jumlah pasien yang sedikit (sampai dengan bulan mei } \\
\text { 2021). Sedangkan bulan juni terjadi lonjakan kasus } \\
\text { yang tinggi sehingga ada pembatasan jumlah pasien } \\
\text { 3. Terdapat beberapa jenis layanan yang tidak dilakukan } \\
\text { selama pandemi covid 19 yaitu tindakan yang } \\
\text { menyebabkan keluarnya aerosol di pelayanan gigi } \\
\text { seperti scalling dan penambalan Sedangkan pencabutan } \\
\text { tidak dilaksanakan karena waktu interaksi yang lama } \\
\text { dan resiko saat anastesi. } \\
\text { 4. Penggunaan APD (Alat Pelindung Diri) sesuai Level } \\
\text { resiko pada tiap pelayanan } \\
\text { 5. Desinfeksi ruangan sebelum dan sesudah pelayanan }\end{array}$ \\
\hline 2. & Fungsi UKM & $\begin{array}{l}\text { Terdapat perubahan pada fungsi UKM yaitu : } \\
\text { 1. Pembatasan jumlah masyarakat dalam pelayanan luar } \\
\text { Gedung (posyandu, posbindu, dll) dilakukan shift } 5 \\
\text { pasien satu kali shift dengan rentang waktu } 1 \text { jam } \\
\text { untuk } 5 \text { pasien berikutnya. } \\
\text { 2. Beberapa kegiatan yang berhubungan dengan sekolah } \\
\text { tidak dapat dilaksanakan seperti sosialisasi dan } \\
\text { penyuluhan ke anak sekolah untuk semua program } \\
\text { (pemeriksaan gigi mulut, Upaya Kesehatan Sekolah } \\
\text { (UKS), pemberian tablet tambah darah, penilaian } \\
\text { PHBS sekolah, BIAS (Bulan Imunisasi Anak Sekolah) } \\
\text { dll } \\
\text { Penggunaan APD dan protocol Kesehatan untuk setiap } \\
\text { jenis kegiatan UKM } \\
\text { 4. Penempatan Sarana Prasarana yang memudahkan } \\
\text { protocol covid seperti sarana cuci tangan, hand } \\
\text { sanitizer, masker) } \\
\text { Kegiatan penyuluhan dilaksanakan dalam Gedung } \\
\text { dengan pembatasan jumlah sedangkan penyuluhan di } \\
\text { luar gedung tidak dapat dilaksanakan karena } \\
\text { menghindari pengumpulan masa. Adapun } \\
\text { dilaksanakan menggunakan strategi khusus seperti } \\
\text { penggunaan mobil untuk sosialisasi menggunakan } \\
\text { pengeras suara atau penggunaan media social. }\end{array}$ \\
\hline
\end{tabular}




\begin{tabular}{|l|l|l|}
\hline & $\begin{array}{l}\text { 6. } \\
\text { Penyebarluasan informasi menggunakan media social } \\
\text { seperti Instagram, facebook, media online seperti Wa } \\
\text { group. }\end{array}$ \\
\hline
\end{tabular}

Berdasarkan hasil observasi di atas maka dapat disimpulkan bahwa puskesmas tetap melaksanakan fungsinya sebagai UKP dan UKM sesuai dengan yang disebutkan di dalam Permenkes no 43 th 2019. Tetapi menggunakan berbagai strategi mengingat penyebaran covid 19 yang sangt cepat seperti perubahan alur pasien, pemanfaatan sarana prasarana, ketatnya protocol kesehatan, desinfesi sebalum dan sesudah pelayanan (fungsi UKP) sedangkan untuk fungsi UKM karena tidak boleh adanya kerumunan maka puskesmas menggunakan media social dan memperkuat hubungan lintas sector dalam penyebarluasan informasi di masyarakat dari tk RT sampai kecamatan termasuk jejaring kesehatan.Hal ini bertujuan untuk melindungi tenaga kesehatan dan masyarakat dari kemungkinan terpapar di tempat kerja. Sedangkan untuk wawancara mendalam dilakukan kepada pemangku kebijakan terkait pelaksanaan fungsi puskesmas baik manajemen Puskesmas maupun stakeholder di Dinas Kesehatan Kabupaten Bandung.

Berdasarkan hasil wawancara dengan stake holder dilakukan melalui 2 cara yaitu melalui media online dan melalui tatap muka. Hal ini dikarenakan saat wawancara masih dalam kondisi pandemic covid 19. Wawancara mengacu kepada teori Merille s Grindle yang dibagi menjadi konten isi dan konten implementasi. Adapun berdasarkan hasil wawancara dapat disimpulkan bahwa Dinas Kesehatan melalui berbagai program telah mengeluarkan berbagai kebijakan terkait pelaksanaan kegiatan di puskesmas dalam menjalankan fungsinya di masa pandemic covid 19 seperti Surat Edaran, Surat Himbauan, Surat kesiapsiagaan menghadapi pandemi covid yang intinya kegiatan di puskesmas tetap bisa dilaksanakan seperti termaktub dalam permenkes 43 th 2019 tetapi menggunakan protocol kesehatan dilengkapi sarana prasarana seperti sarana cuci tangan, penggunaan Alat Pelindung Diri yang bertujuan untuk melindungi masyarat dan juga tenaga kesehatan dari terpapar oleh covid 19. Sedangkan untuk pergeseran anggaran mengacu pada Permendagri No. 79/2018 yang menyebutkan bila mana dimungkinkan dilakukan pergeseran anggaran. Maka pergeseran dapat dilakukan karena bersifat fleksibel. Pergeseran anggaran dilakukan di akhir bulan maret untuk keperluan logistik dalam menghadapi pandemic. Selain perubahan anggaran dari BLUD puskesmas , Pemerintah Daerah Kabupaten Bandung termasuk di dalamnya Dinas Kesehatan juga melakukan pergeseran anggaran untuk membantu bidang kesehatan dalam memenuhi kebutuhan untuk penanganan pandemic covid 19. Tetapi untuk Pengajuan kebutuhan logistic dan anggaran tetap dilakukan oleh Puskesmas. Untuk pelaksanaan fungsi Upaya Kesehatan Masyarakat memang agak terkendala karena sifat virus yang menyebar cepat tidak dimungkinkan untuk mengumpulkan keramaian maka ada beberapa kegiatan yang tidak dapat dilaksanakan seperti Upaya Kesehatan Sekolah, Bulan Imunisasi Sekolah (BIAS), penyuluhan luar gedung, Kesehatan Lingkungan, dan lainlain hal ini tentu berdampak pada capaian kinerja dimana 
target yang telah ditetapkan tidak dapat dicapai. Sehingga capaian kinerja sesuai Standar Pelayaan Minimal (SPM) yang harus dilakukan oleh Puskesmas tidak tercapai. Berdasarkan feedback hasil capaian kinerja Puskesmas (PKP) tahun 2020 puskesmas margahayu selatan masuk dalam kategori kurang. Diperlukan strategi khusus untuk dapat melaksanakan kegiatan preventif promotif di masa pandemi ini dan tetap menjalankan fungsinya untuk mencapai target kinerja. Adanya kegiatan yang tidak dapat dilaksanakan di masa pandemic tentu berakibat rendahnya penyerapan anggaran untuk kegiatan masyarakat yaitu hanya terserap 29,1\%. dari total anggaran.

\section{KESIMPULAN DAN SARAN}

Berdasarkan teori Merilee S.Grindle (1980), suatu kebijakan akan berhasil dipengaruhi oleh dua variable yakni Isi Kebijakan (Conten of policy) dan Lingkungan implementasi (Context of implementartion). Berdasarkan Isi kebijakan, (1) Indicator kepentingan sasaran yang mempengaruhi kebijakan adalah tenaga kesehatan di Puskesmas dan Rumah sakit serta masyarakat wilayah kerja Kabupaten Bandung.(2) indicator Jenis manfaat yang diterima dapat menekan penambahan kasus covid 19 di wilayah kerja puskesmas, (3) derajat perubahan yang terjadi yaiu merubah perilaku masyarakat pengunjung untuk menggunakan protocol Kesehatan (4) indicator Kedudukan pembuat kebijakan disimpulkan bahwa di Tingkat Kabupaten, Dinas kesehatan mengeluarkan berbagai kebijakan yang harus dilaksanakan Puskesmas untuk menjalankan fungsinya di masa pandemic covid 19. sedangkan ditingkat Puskesmas Kepala Puskesmas diberi wewenang dalam membuat kebijakan internal terkait pelaksanaan fungsi UKP UKM (5) indicator pelaksana kebijakan disimpulkan bahwa Dinas Kesehatan sebagai SKPD diatas puskesmas mengeluarkan berbagai kebijakan yang mendukung dilaksanakannya fungsi UKM UKP di Puskesmas berupa payung hukum seperti Surat edaran, surat himbauan, dan juga peningkatan sumber sumber daya.manusia.yang.kompeten berupa OJT (On Job Training), workshop, desiminasi infomasi terkait penatalaksanaan dalam menghadapi pandemic covid 19 . Sedangkan di tingkat Puskesmas melaksanakan kebijakan sesuai dengan arahan dari Dinas Kesehatan dan menyesuaikan dengan karakteristik dan potensi daerah.

Sedangkan berdasarkan Lingkungan Kebijakan untuk indicator (1) Seberapa besar kekuasaan, kepentingan, strategi dan actor yang terlibat, berdasarkan hasil wawancara diketahui bahwa walaupun Kementerian Kesehatan dan Dinas Kesehatan mengeluarkan berbagai kebijakan mengenai pelaksanaan kegiatan di Puskesmas sesuai fungsi Puskesmas, tetapi strategi dan actor yang menentukan berhasil tidaknya adalah manajemen puskesmas sesuai dengan struktur organisasi yang ada. (2) karakteristik institusi/Lembaga yang sedang berkuasa, bahwa puskesmas memiliki karakter yang beragam tergantung dari potensi, masalah serta karakter daerah maka kebijakan dan wewenang dari kepala puskesmas yang mengetahui karakter daerah masingmasing untuk mengeluarkan kebijakan dalam melaksanakan fungsinya di masa pandemic ini, sedangkan Dinkes Kabupaten melaksanakan pengawasan dan pembinaan pada Puskesmas .(3) tingkat kepatuhan dan responsivitas dari kelompok sasaran, dari hasil kuesioner maupun observasi masyarakat mematuhi kebijakan yang berlaku dan memahami tujuan dan manfaatnya. 
Dari hasil wawancara diketahui bahwa baik tingkat Puskesmas maupun Dinas Kesehatan mengeluarkan kebijakan terkait optimalisasi pelaksanaan fungsi Puskesmas sesuai dengan Permenkes 43 tahun 2019 di saat pandemi covid 19. Seperti dengan adanya himbauan penggunaan protocol Kesehatan, perubahan anggaran untuk ketersediaan sarana prasarana pencegahan Covid 19, dukungan sumber daya manusia yang kompeten dan sarana prasarana untuk menunjang pelaksanaan pelayanan di puskesmas baik di dalam maupun di luar Gedung.

Berbagi strategi juga dilaksanakan agar capaian kinerja puskesmas khususnya dalam pelaksanaan fungsi Upaya Kesehatan masyarakat tetap bisa optimal. Penyebarluasan informasi yang tepat sasaran. Masyarakat memahami tujuan, rincian kegiatan dan manfaat yang diambil dari kebijakan yang diambil oleh puskesmas. Hal ini menunjukkan bahwa fungsi puskesmas dalam menyebarluaskan informasi kepada masyakat terkait edukasi mengenai penanganan covid di Puskesmas sampai kepada masyarakat. Sosialisasi atau penyebarluasan informasi adalah merupakan fungsi puskesmas sebagai UKM (Upaya Kesehatan Masyarakat) yaitu meningkakan pengetahuan masyarakat sehingga memahami pesan yang disampaikan. Dengan mengetahui pandemi covid 19, diharapkan masyarakat dapat ikut serta bersama-sama menjadi mitra puskesmas dalam memberi informasi dan merubah perilaku masyakat terkait adanya pandemi covid 19 sehingga dapat menekan kasus penambahan covid di wilayah kerja puskesmas.

Walaupun demikian, beberapa kegiatan terkait program lain di luar covid seperti terabaikan, Penilaian Kinerja Puskesmas (PKP) yang merupakan indicator kinerja puskesmas berdasarkan Keputusan Menteri Kesehatan tentang Standar Pelayanan Minimal tidak mencapai target, Hal ini disebabkan banyaknya kegiatan yang tidak dilaksanakan terkait fungsi UKM dan rendahnya penyerapan anggaran (29,1\%)

Berdasarkan kesimpulan diatas, maka saran penulis adalah Diperlukan kajian yang membutuhkan wawasan dan disiplin ilmu yang mumpuni untuk implementasi suatu kebijakan yang disiapkan dalam menghadapi berbagai kondisi tak terduga seperti pandemic covid 19, Diperlukan fleksibilitas dalam pelaksanaan fungsi puskesmas disesuaikan dengan kondisi, potensi dan masalah di puskesmas.

\section{DAFTAR PUSTAKA}

Kementerian Ppn/Bappenas 2018, .Kedeputian Pembangunan Manusia, Masyarakat Dan Kebudayaan, Penguatan Pelayanan Kesehatan Dasar Di Puskesmas

Chicy Widya Morfi1, Ahmad Junaidi1, Elsesmita1, Diana Nur Asrini1, Freidlander Pangestu2, Dya Mulya Lestari2, Irvan Medison1, Russilawati1, Fauzar3, Roza Kurniati3, Finny Fitry Yani2, Kajian Terkini Coronavirus Disease 2019 (Covid-19), Jurnal Online Ilmu Kesehatan Indonesia

Peraturan Menteri Kesehatan Republik Indonesia No 75 Th 2014 Tentang Puskesmas

Dr. Riant Nugroho, Public Policy, Dinamika Kebijakan Publik, Analisis Kebijakan Publik, Manajemen Politik Kebijakan Public, Etika Kebijakan Public , Kimia kebijakan Public Edisi 6. Yusufa Ibnu Sina Setiawan ,Program Studi Magister Ilmu Hukum Universitas Muhammadiyah Malang, 2019 Penetapan Karantina Wilayah Menurut 
Pandangan Legal Positivisme Dalam Rangka Pencegahan Dan Pemberantasan Pandemi Coronavirus Disease (Covid)-19, Jurnal Online

Nailul Mona Program Studi Periklanan Kreatif Program Pendidikan Vokasi, Universitas Indonesia, 2020 "Konsep Isolasi Dalam Jaringan Sosial Untuk Meminimalisasi Efek Contagious (Kasus Penyebaran Virus Corona Di Indonesia), Jurnal Online

Tim Penanganan Kasus Pasien Dengan Penyakit Infeksi New Emerging Dan Re-Emerging Disease (Pinere) Rsupn Dr. Cipto Mangunkusumo, Jakarta, Departemen Ilmu Penyakit Dalam Fakultas Kedokteran Universitas Indonesia Rsupn Dr. Cipto Mangunkusumo, Jakarta, 2020, Tinjauan Literatur Terkini Coronavirus Disease 2019, Jurnal Online

Zahrotunnimah1 Universitas Ibn Khaldun Bogor,2020, Langkah Taktis Pemerintah Daerah Dalam Pencegahan Penyebaran Virus Corona Covid-19 Di Indonesia, Jurnal Online

Tri Agus Setiawan Agus Ilyas, Ari Putra Wibowo Stmik Widya Pratama Pekalongan, 2020, "Pencegahan Dan Edukasi Masyarakat Dalam Penanganan Endemik Penyakit Berbasis Web Untuk Peningkatan Kesehatan Masyarakat Di Kota Pekalongan”, Jurnal Online

Afni Regita Cahyani Muis Universitas Darussalam Gontor, Ponorogo Indonesia, 2020, Transparansi Kebijakan Publik Sebagai Strategi Nasional Dalam Menanggulangi Pandemi Covid-19, Jurnal Online

Nur Rohim Yunus,1 Annissa Rezki2 Universitas Islam Negeri Syarif Hidayatullah Jakart, 2020 “ Kebijakan Pemberlakuan Lockdown Sebagai Antisipasi Penyebaran Corona Virus Covid-19”, Jurnal Online
Siti Nurhalimah, Universitas Islam Negeri Syarif Hidayatullah Jakarta,2020, Covid-19 Dan Hak Masyarakat Atas Kesehatan

Anggia Valerisha , Marshell Adi Putra, Fakultas Ilmu Sosial Dan Ilmu Politik, Universitas Katolik Parahyangan, Indonesia, 2020, "Pandemi Global Covid-19 Dan Problematika NegaraBangsa: Transparansi Data Sebagai Vaksin Socio-Digital?”, , Jurnal Online

Dana Riksa Buana1 National Research Tomsk State University \& Universitas Mercu Buana, Jakarta, 2020, “Analisis Perilaku Masyarakat Indonesia Dalam Menghadapi Pandemi Virus Corona (Covid-19) Dan Kiat Menjaga Kesejahteraan Jiwa”, , Jurnal Online

Keputusan Menteri Kesehatan Republik Indonesia Nomor Hk.01.07/Menkes/413/2020 Tentang Pedoman Pencegahan Dan Pengendalian Coronavirus Disease 2019 (Covid-19)

Kementeraian Kesehatan Republki Indonesia, Direktur Mutu \& Akreditasi Pelayanan Kesehatan 2020 , Mutu Pelayanan Faskes Era New Normal

Direktorat Pelayanan Kesehatan Primer Direktorat Jenderal Pelayanan Kesehatan Kementerian Kesehatan Republik Indonesia, Petunjuk Teknis Pelayanan Puskesmas Pada Masa Pandemi Covid-19

Rudi Susilana, Nana Sujana Jurusan Kurikulum Universitas Pendidikan Indonesia, 2004, Pendekatan Penelitian Kualitatif, Handout Pendekatan Penelitian Kualitatif

Dr. Eng Lilya Susanti, Direktur Riset Tekhnologi Dan Pendidikan Tinggi Fakultas Tekhnik Universitas Brawijaya , Metode Penelitian Kualitatif 
Implementasi Kebijakan Fungsi Puskesmas Selama Pandemi Covid 19 Di Puskesmas Margahayu Selatan Kabupaten Bandung (Yulianti Hasanah, Ratna Meisa Dai, Deasy Silvya Sari)

Departemen Kesehatan Republik

Indonesia, Pedoman Pencegahan dan Pengendalian CoronaVirus Disease (COVID 19), Juli 2020 